Journal of Helminthology

cambridge.org/jhl

\section{Research Paper}

Cite this article: Palumbo E, Servián A, Sánchez R, Diaz JI (2020). A new species of Hedruris (Nematoda: Hedruridae) from freshwater turtles, its life cycle and biogeographic distribution of the genus. Journal of Helminthology 94, e93, 1-11. https:// doi.org/10.1017/S0022149X19000877

Received: 7 June 2019

Revised: 26 August 2019

Accepted: 29 August 2019

\section{Key words:}

Hedruris; Hydromedusa tectifera; Phrynops hilarii; Nematoda; Neotropics; parasites; turtles

Author for correspondence:

E. Palumbo, E-mail: epalumbo@cepave.edu.ar

\title{
A new species of Hedruris (Nematoda: Hedruridae) from freshwater turtles, its life cycle and biogeographic distribution of the genus
}

\section{E. Palumbo ${ }^{1} \mathbb{D}$, A. Servián ${ }^{1}$, R. Sánchez ${ }^{2}$ and J.I. Diaz ${ }^{1}$}

${ }^{1}$ Centro de Estudios Parasitológicos y de Vectores, FCNyM, UNLP, CONICET, Boulevard $120 \mathrm{~s} / \mathrm{n}$ e/61 y 62, 1900 La
Plata, Buenos Aires, Argentina and ${ }^{2}$ Instituto de Limnología Dr. R.A. Ringuelet, FCNyM, UNLP, CONICET, Boulevard
120 s/n e/61 y 62, 1900 La Plata, Buenos Aires, Argentina

\section{Abstract}

We describe Hedruris dratini n. sp. (Nematoda, Hedruridae) from Hydromedusa tectifera and Phrynops hilarii in Argentina based on morphological and molecular characters. Also, we provide information about its life cycle. The new species differs from other species of the genus by possessing the excretory pore, nerve ring and deirids at equal distance from the anterior end. Additionally, $H$. dratini n. sp. has mammilated eggs and males possess nine pairs of caudal papillae. The subadults and adults of $H$. dratini n. sp and $H$. orestiae were characterized by sequencing the small subunit ribosomal DNA (18S). We present for the first time a life cycle of a species of Hedruris that includes an amphipod as intermediate host and a reptile as definitive host. Furthermore, we analysed the host and geographic distribution of all Hedruris species. Although the genus has a cosmopolitan distribution and parasitizes a great host diversity, the majority of species have a Gondwanian distribution, with amphibians being the preferred hosts.

\section{Introduction}

The species of the genus Hedruris Nitzsch, 1821 are parasites of the digestive tract of lampreys, fish, amphibians and reptiles, commonly found in their stomach and duodenum. Females attach to the epithelial wall using a characteristic eversible hook situated in their caudal end, while males are found either coiled around the female ones or free in the stomach lumen (Baker, 1982, 1986; Blair, 1984). The genus is widely distributed and comprises 28 species, four of which are considered doubtful, that is, Hedruris iheringi Pereira \& Vaz, 1933, H. hylae Johnston \& Mawson, 1941, H. scabra Freitas \& Lent, 1941 and H. marinus Kurochkin \& Korotaeva, 1974 (Baker, 1982, 1986; Ramadan et al., 2014; Jones \& Resasco, 2016; Rossin \& Timi, 2016). In the Neotropical region, nine species of Hedruris were recorded: $H$. siredonis Baird, 1858, H. orestiae Moniez, 1889, H. mucronifer Schuurmans Stekhoven, 1951, H. basilichtensis Mateo, 1971, H. juninensis Bendezú, 1976, H. moniezi Ibañez \& Córdova, 1976, H. heyeri Bursey \& Goldberg, 2007, H. suttonae Brugni \& Viozzi, 2010 and H. bifida Rossin \& Timi, 2016. Among them, only H. mucronifer, H. suttonae, H. bifida and H. orestiae occur in Argentina (Bursey \& Goldberg, 2000; Palumbo et al., 2016; Rossin \& Timi, 2016; Serrano-Martinez et al., 2017).

Only two valid species of Hedruris were reported in freshwater turtles: H. pendula (Leidy, 1851), which parasitizes the painted turtle Chrysemys picta (Schneider, 1783), the spotted turtle Clemmys guttata (Schneider, 1792) and the Blanding's turtle Emys blandingii (Holbrook, 1838) in Canada, United States, France and Germany (in a zoo), and H. orestiae, which parasitizes the Argentine snake-necked turtle Hydromedusa tectifera Cope, 1870 in Buenos Aires, Argentina (Baker, 1982; Palumbo et al., 2016).

Only two species of the genus were molecularly characterized: (i) Luque et al. (2010) sequenced a partial region of the $18 \mathrm{~S}$ and the third domain of $28 \mathrm{~S}$ (D3) rRNA genes from 16 isolates of Hedruris spinigera Baylis, 1931 from Retropinna retropinna Richardson, 1848 and Paracorophium excavatum (Thomson, 1884); (ii) Choudhury \& Nadler (2018) sequenced a partial region of the18S gene from one isolate of Hedruris sp. from salamander Taricha granulosa (Skilton, 1849). Thus, little molecular data are accessible at GenBank to make comparative analyses.

Information is available on the life cycles of four species of the genus Hedruris: H. androphora Nitzsch, 1821 and $H$. ijimai Morishita, 1926 require isopods of the genus Asellus Geoffroy, 1762 as intermediate host and amphibians as definitive host (Petter, 1971; Hasegawa \& Otsuru, 1979), whereas $H$. spinigera and $H$. suttonae need amphipods as 
intermediate hosts (Paracorophium Stebbing, 1899 and Hyalella Smith, 1874, respectively) and fishes as definitive hosts (Petter, 1971; Hasegawa \& Otsuru, 1979; Brugni \& Viozzi, 2010; Luque et al., 2010).

In this work, we describe a new species of Hedruris parasitizing two species of freshwater turtles, Hyd. tectifera and the Hilaire's toad-headed turtle Phrynops hilarii (Duméril \& Bibron, 1835), in streams of Buenos Aires province, Argentina, based on morphological and molecular data. In addition, we provide information about its life cycle based on the larval stages recovered from its intermediate host Hyalella bonariensis Freitas dos Santos, Araujo \& Bond-Buckup, 2008. Moreover, we update the host and geographic distributions of all species in the genus Hedruris.

\section{Material and methods}

\section{Sampling}

Between December 2016 and November 2017, stomach contents and faecal matter were obtained from $47 \mathrm{Hyd}$. tectifera and two $P$. hilarii in the stream Rodríguez (SR) $\left(34^{\circ} 53^{\prime} 02^{\prime \prime} \mathrm{S}, 58^{\circ}\right.$ $\left.02^{\prime} 30^{\prime \prime} \mathrm{W}\right), 16 \mathrm{Hyd}$. tectifera in the stream Carnaval (SC) $\left(34^{\circ}\right.$ $\left.52^{\prime} 20^{\prime \prime} \mathrm{S}, 58^{\circ} 05^{\prime} 22^{\prime \prime} \mathrm{W}\right)$ and $14 \mathrm{Hyd}$. tectifera in the stream El Gato (SG) $\left(34^{\circ} 53^{\prime} 26^{\prime \prime} \mathrm{S}, 57^{\circ} 59^{\prime} 40^{\prime \prime} \mathrm{W}\right)$ in Buenos Aires province, Argentina. The geodetic datum of the geographic coordinates is WGS84. Stomach washes were collected according to the methods of Legler (1977) and then preserved in 70\% ethanol. Faecal samples were preserved in $70 \%$ ethanol. All samples were analysed using a stereoscopic microscope (Olympus SZ61, Tokyo, Japan); the nematodes and prey items were quantified and preserved in $70 \%$ ethanol. In addition, a single Hyd. tectifera specimen found dead on the road to the stream Rodríguez in October 2017 was necropsied. It was fixed in $10 \%$ formaldehyde for further analysis.

In order to find larval stages in the intermediate hosts, we examined the crustaceans found in the stomach contents of the turtles. Moreover, 100 amphipods were collected in the stream Rodriguez by a plankton net.

\section{Morphological identification}

For morphological studies under a compound microscope (Olympus BX51, Tokyo, Japan), nematodes were temporarily mounted and cleared in Amman's Lactophenol. Additionally, photographs were taken with a Q-Imaging Go-3 digital camera. Drawings were made with the aid of a camera lucida. Some specimens were dehydrated, critical point dried, gold coated and observed and photographed using a scanning electron microscope (Jeol/SET 100, Tokyo, Japan). Nematodes were identified according to Yamaguti (1961), Ibañez \& Córdova (1976), Baker (1986) and Moravec \& Vargas-Vázquez (1998). Measurements are given in micrometres unless otherwise indicated. The number $(n)$, prevalence $(\mathrm{P})$ and mean intensity (MI) of nematodes were calculated following Bush et al. (1997) and using the Quantitative Parasitology Program (QP 3.0, Rozsa et al., 2000). Voucher specimens were deposited in the Helminthological Collection of the Museo de La Plata, La Plata, Buenos Aires province, Argentina.

The crustaceans were cleared using Amman's Lactophenol and examined for endoparasites under a stereoscopic microscope.

\section{Molecular and polymerase chain reaction (PCR) methods}

A total of 14 individual nematodes were isolated in Eppendorf tubes and frozen at $-20^{\circ} \mathrm{C}$ for subsequent DNA extraction and genotyping: nine adult specimens from the stomach of $\mathrm{Hyd}$. tectifera (five males and four females) and five subadults from $H y$. bonariensis. DNA was extracted from the isolates using $200 \mu \mathrm{l}$ of 5\% Chelex solution (Bio-Rad Laboratories, CA, USA) containing $0.2 \mathrm{mg} / \mathrm{ml}$ Proteinase $\mathrm{K}$ (Roche), incubated at $56^{\circ} \mathrm{C}$ overnight, followed by $10 \mathrm{~min}$ at $95^{\circ} \mathrm{C}$. Nuclear $18 \mathrm{~S}$ rDNA amplification was done using primers Nem_18S_F and Nem_18S_R (Floyd et al., 2005), which span approximately $900 \mathrm{bp}$ of the gene Each $50 \mu \mathrm{l}$ PCR contained $25 \mu \mathrm{l}$ of GoTaq Green Master Mix (Promega, Madison, WI, USA), $2.5 \mu$ of each primer, $17 \mu$ l of water and $3 \mu \mathrm{l}$ of extracted DNA. PCR amplifications for $18 \mathrm{~S}$ were performed using an Eppendorf Mastercycler ep gradient S (Thermal Cycler 96 WELL, Hamburg, Germany), consisting of $94^{\circ} \mathrm{C}$ for $15 \mathrm{~min}$, followed by 35 cycles of $94^{\circ} \mathrm{C}$ for $30 \mathrm{~s}, 60^{\circ} \mathrm{C}$ for $30 \mathrm{~s}$ and $72^{\circ} \mathrm{C}$ for $70 \mathrm{~s}$, with a final extension of $72^{\circ} \mathrm{C}$ for $240 \mathrm{~s}$. PCR products were further purified and sequenced (Macrogen, South Korea). Sequences were edited and aligned using Chromas version 2.6.6 ${ }^{\circledR}$ and Gap version 4.11.2 ${ }^{\circledR}$ (Bonfield et al., 1995) then compared to the NCBI database using BLAST version 2.2.26 (Altschul et al., 1997) to identify sequences with high similarity to DNA sequences obtained.

\section{Phylogenetic analyses}

The newly obtained $18 \mathrm{~S}$ sequences were aligned with other sequences of Hedruris available in the GenBank using CLUSTAL W program (Larkin et al., 2007). The phylogenetic tree was reconstructed using the Maximum Likelihood method and the genetic distance was estimated using Kimura's (1980) two-parameter (K2-P) model implemented in the Mega 7.0.26 program (Kumar et al., 2016). A sequence of one Spiruridae species (GenBank accession number JQ771746) was included as outgroup. Bootstrap analyses were conducted using 500 replicates. The genetic differences in datasets were also calculated with Mega program, using uncorrected $p$-distances.

\section{Host and geographic distribution}

To estimate the host and geographic distribution of the genus Hedruris, an exhaustive analysis was made of the available bibliography up to 2018. Publications in indexed journals and records in renowned books were taken into account.

\section{Results}

A total of 2573 nematodes were obtained from the visceral dissection, stomach washes and faecal samples of the turtles examined, whereas 24 nematodes (one fourth-stage larva and 23 subadults) were recovered from the $H y$. bonariensis specimens collected from the stream Rodriguez. Every time amphipods were found in the turtle's stomach contents, at least one of them was parasitized. Both adult and larval nematodes found belonged to the genus Hedruris. Only ten adult and one subadult specimens from eight Hyd. tectifera and one subadult found in $\mathrm{Hy}$. bonariensis from the stream Rodriguez were identified as $H$. orestiae. The remainder nematodes belonged to a new species of the genus Hedruris, which is described in the following. 


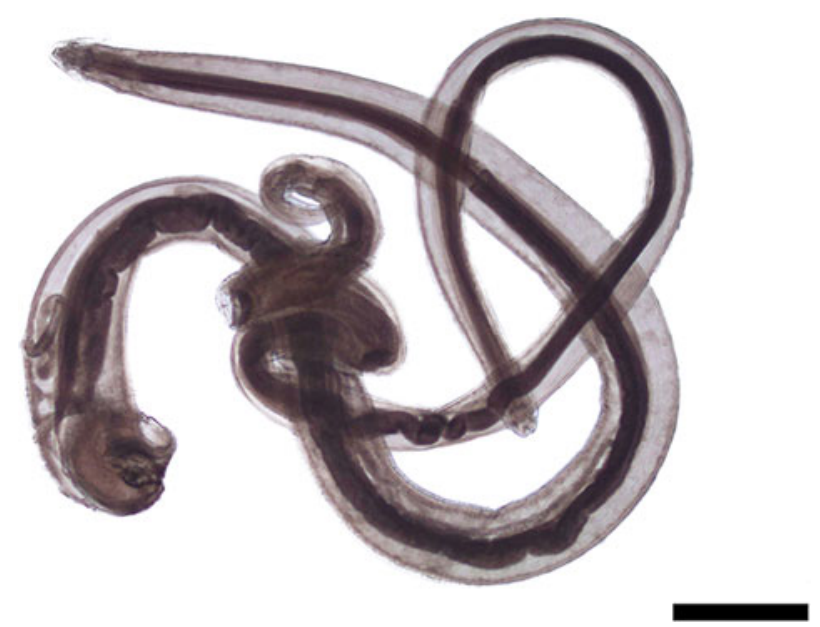

Fig. 1. Male of Hedruris dratini n. sp. encircling female. Scale bar: $500 \mu \mathrm{m}$.

\section{Systematics}

Hedruridae Railliet, 1916

Hedrurinae Chitwood \& Wehr, 1934

Hedruris Nitzsch, 1821

Hedruris dratini n. sp.

\section{Taxonomic summary}

Type host. Hydromedusa tectifera Cope, 1870 (Pleurodira, Chelidae).

Other hosts. Phrynops hilarii (Duméril \& Bibron, 1835) (Pleurodira, Chelidae); Hy. bonariensis Freitas dos Santos, Araujo \& Bond-Buckup, 2008 (Amphipoda).

Type locality. Stream Rodríguez $\left(34^{\circ} 53^{\prime} 02^{\prime \prime} \mathrm{S}, 58^{\circ} 02^{\prime} 30^{\prime \prime} \mathrm{W}\right.$; datum: WGS84), Buenos Aires province, Argentina.

Other localities. Stream El Gato and stream Carnaval, Buenos Aires province, Argentina.

Type material. Holotype: MLP-He-7510 (male). Paratypes: MLP-He-7511 (two males and two females).

Site of infection. Adults in the stomach of turtles (fig. 1), larvae in the haemocoel of amphipods (fig. 2).

Prevalence $(P)$ and mean intensity (MI) in definitive hosts. Hydromedusa tectifera. SR: $\mathrm{n}=2286, \quad \mathrm{P}=97.8 \%, \quad \mathrm{MI}=51$ (2-198); SG: $\mathrm{n}=2, \mathrm{P}=14 \%, \mathrm{MI}=1$; $\mathrm{SC}: \mathrm{n}=136, \mathrm{P}=43 \%, \mathrm{MI}=$ 19.4 (1-119). Phrynops hilarii. SR: $\mathrm{n}=3, \mathrm{P}=100 \%, \mathrm{MI}=1$.

Prevalence $(P)$ and mean intensity $(M I)$ in the intermediate host. Hyalella bonariensis. SR: $\mathrm{n}=100, \mathrm{P}=23 \%, \mathrm{MI}=1$.

Etymology. The specific name is an arbitrary combination of two words $($ dra $=$ dragon; tini $=$ tiny $)$.

General description (based on 40 specimens) (figs 3 and 4). Body cuticle thick, transversally striated. Cephalic end with two large lateral pseudolabia, each bearing a pair of small apical digitiform papillae, a pair of lateral sessile papillae and an amphid. Base of each pseudolabium supported by posteriorly directed cuticular ridge. Dorsal and ventral interlabium between pseudolabia, each with anteriorly directed lobe, curved over surface of apical region, and two bifurcated lateral cuticular structures; cuticular ridge

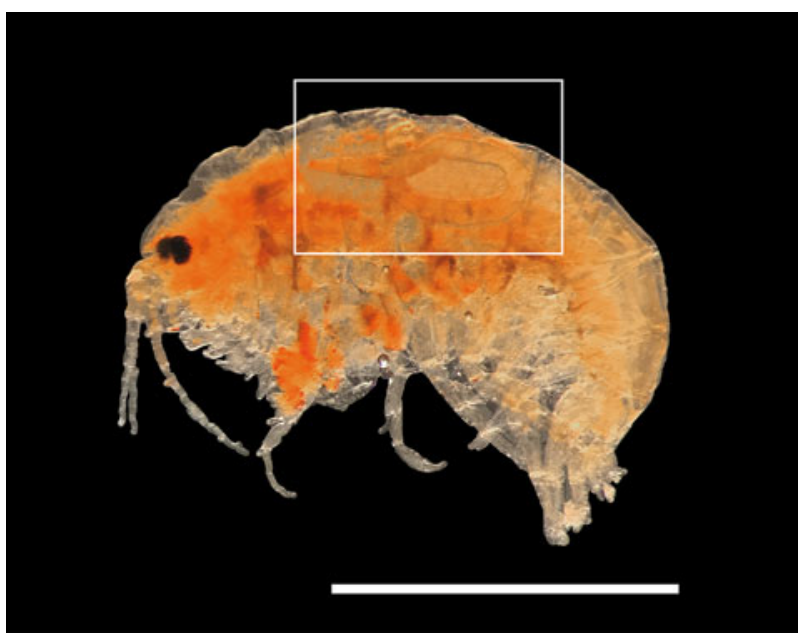

Fig. 2. Hyalella bonariensis with subadult of Hedruris dratini n. sp. (white square). Scale bar: $1 \mathrm{~mm}$.

posteriorly directed between bifurcations. Base of each interlabium supported by a large, posteriorly directed ridge. Buccal cavity thin-walled, oesophagus not clearly divided into muscular and glandular portions. Deirids simple, situated at level of excretory pore and just anterior to nerve ring. Female with posterior sclerotized hook for attachment to host; male generally found encircling female.

Male (based on 20 specimens measured) (figs $3 \mathrm{~b}$ and $4 \mathrm{c}$ ). Body length $5.97(3.64-9.24) \mathrm{mm}$, maximum body width 203 (138-275). Oesophagus $1.07(0.8-1.27) \mathrm{mm}$ long. Deirids and excretory pore at same level, $200(148-245)$ from anterior end. Nerve ring 220 (168-265) from anterior extremity. Posterior end of body with 1-3 coils. Nine pairs of postcloacal papillae: eight pairs subventral and one pair lateral, situated between second last and last pair of subventral papillae. A pair of tiny ventro-lateral phasmids, just posterior to last pair of subventral papillae. Area rugosa with ten ventral longitudinal ridges with scale-like knobs. Spicules 182 (169-233) long, markedly slender, fused in their distal two-thirds, with membranous expansions. Gubernaculum lacking.

Female (based on 20 gravid specimens measured) (figs $3 \mathrm{c}-\mathrm{e}$ and $4 \mathrm{~d})$. Body length 9.1 (7.09-10.94) mm, maximum body width 424 (215-571). Oesophagus 1.7 (1.3-1.8) $\mathrm{mm}$ long. Deirids and excretory pore at same level, 270 (252-285) from anterior end. Nerve ring 295 (275-340) from anterior end. Vulva 716 (465-1127) anterior to anus. Tail bulbous, curved dorsally, with eversible prehensile structure (holdfast) armed with sclerotized hook. Cuticular spines in posterior part of body, distributed in two areas; one with scale-like spines near region of anus, the other with sharply pointed spines on the dorso-lateral surface of holdfast. Didelphic, prodelphic. Egg-filled uteri occupying body cavity completely when gravid. Mammilated eggs 36 (27-41) long and 19 (13-24) wide, operculated at both poles, containing fully developed larva.

Fourth-stage larva (based on one specimen found in $\mathrm{Hy}$. bonariensis) (fig. 5). Cephalic end poorly developed, with interlabia and pseudolabia, but with little development of posterior bridges at base of lips. Digestive tract simple with an anal plug. Cuticle of previous moult observed in posterior region of body. Male larvae with well-developed testicle and a pouch in final part of intestine where primordial spicules appear. 

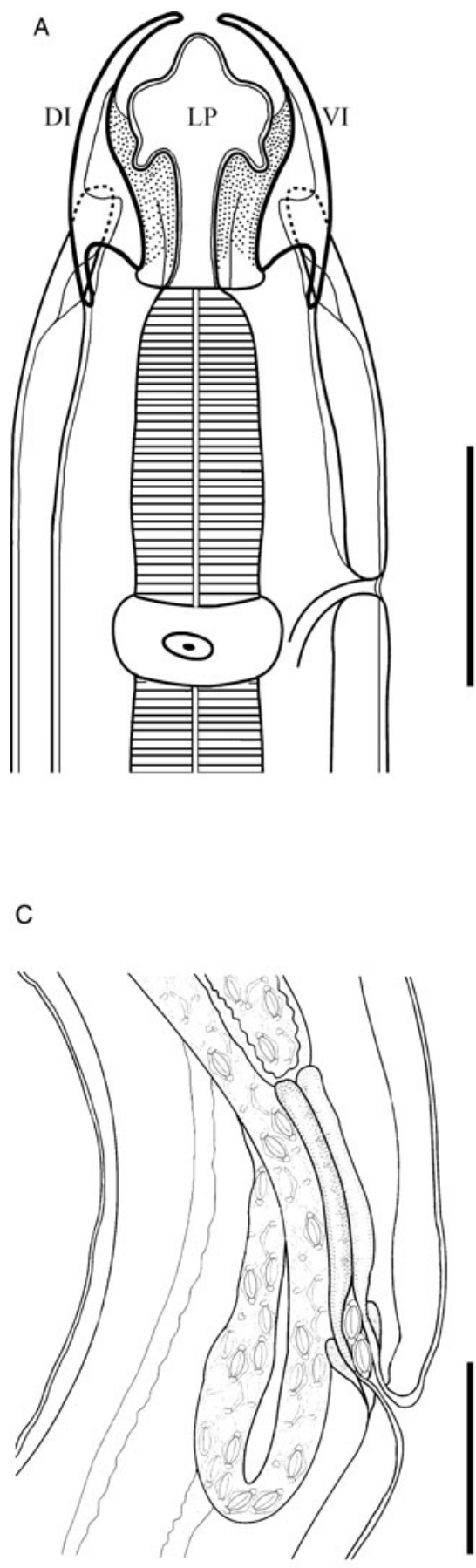

B
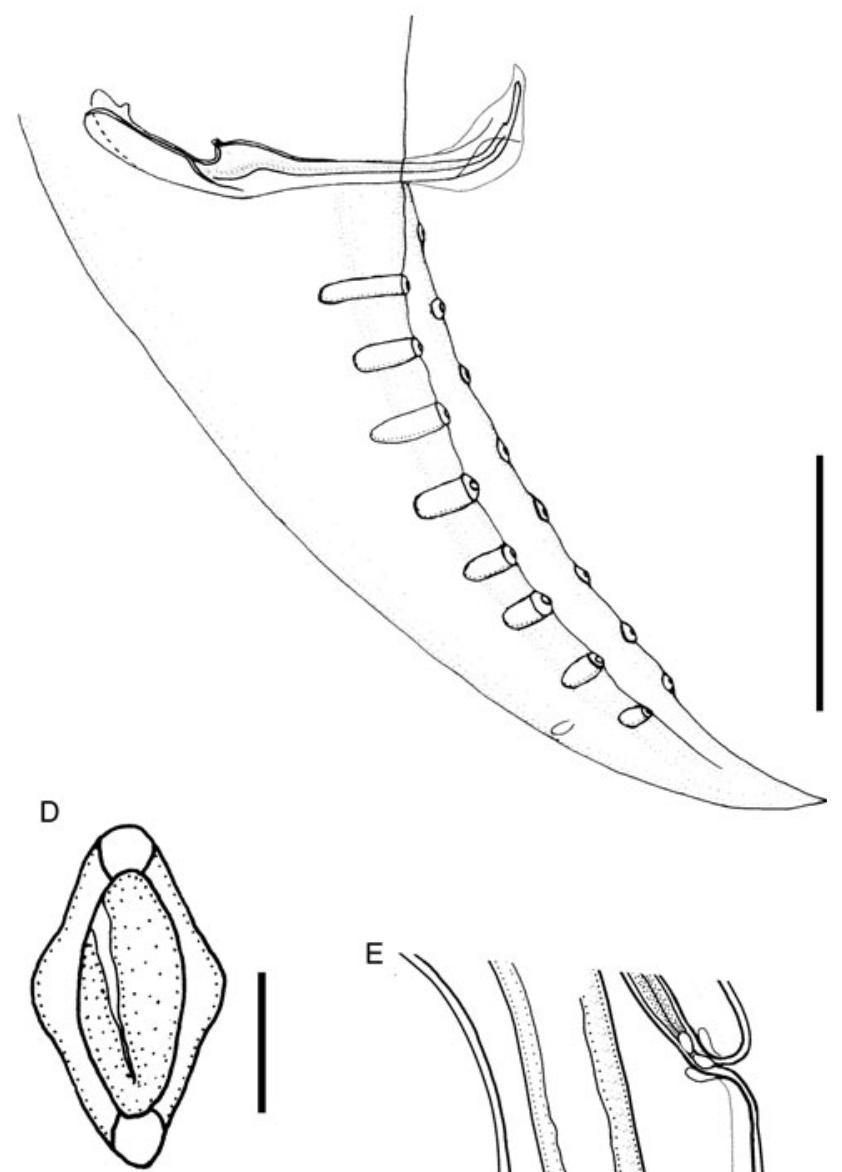

E

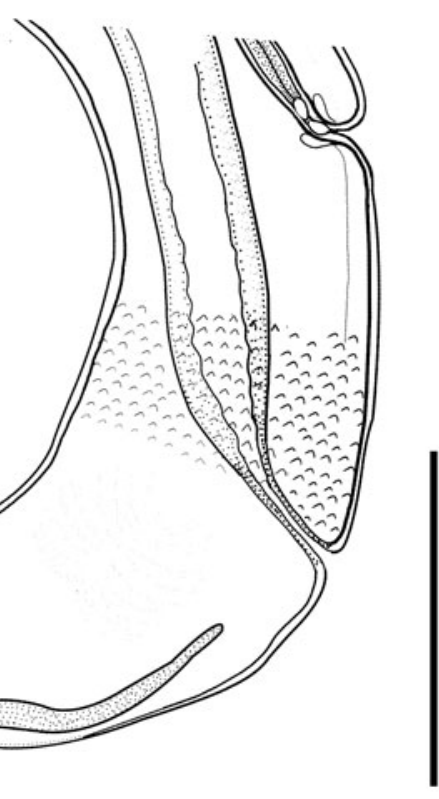

Fig. 3. Line drawings of Hedruris dratini n. sp. (A) Anterior end of female, lateral view; (B) caudal end of male, sublateral view; (C) vulva of female, lateral view; (D) egg; (E) posterior end of female, lateral view. Scale bars: (A, B) $100 \mu \mathrm{m}$; (C) $200 \mu \mathrm{m}$; (D) $20 \mu \mathrm{m}$; (E) $500 \mu \mathrm{m}$. Abbreviations: LP, lateral pseudolabium; DI, dorsal interlabium; VI, ventral interlabium.

Subadult (based on 23 specimens found in Hy. bonariensis). Morphological characteristics of this stage seem to be identical to the adults previously described, but these differ in size and in the degree of development of their reproductive organs (e.g. smaller size of the testes in males and absence of eggs in females).

\section{Remarks}

Hedruris dratini n. sp. can be easily distinguished from all other species of the genus by the position of the deirids in relation to the excretory pore. Both structures are located at the same level in the new species, whereas the excretory pore is located far posterior to the deirids in the rest of the species of the genus. The features commonly used to distinguish species of Hedruris are the shape of the eggs and the number and distribution of the caudal papillae in males (Bursey \& Goldberg, 2000). Among the 24 valid species described to date, only $H$. androphora, $H$. siredonis and $H$. ijimai have mammilated eggs, as in $H$. dratini n. sp. (Baird, 1858; Petter, 1971; Hasegawa \& Otsuru, 1979). However, males of $H$. androphora and $H$. ijimai possess precloacal and 

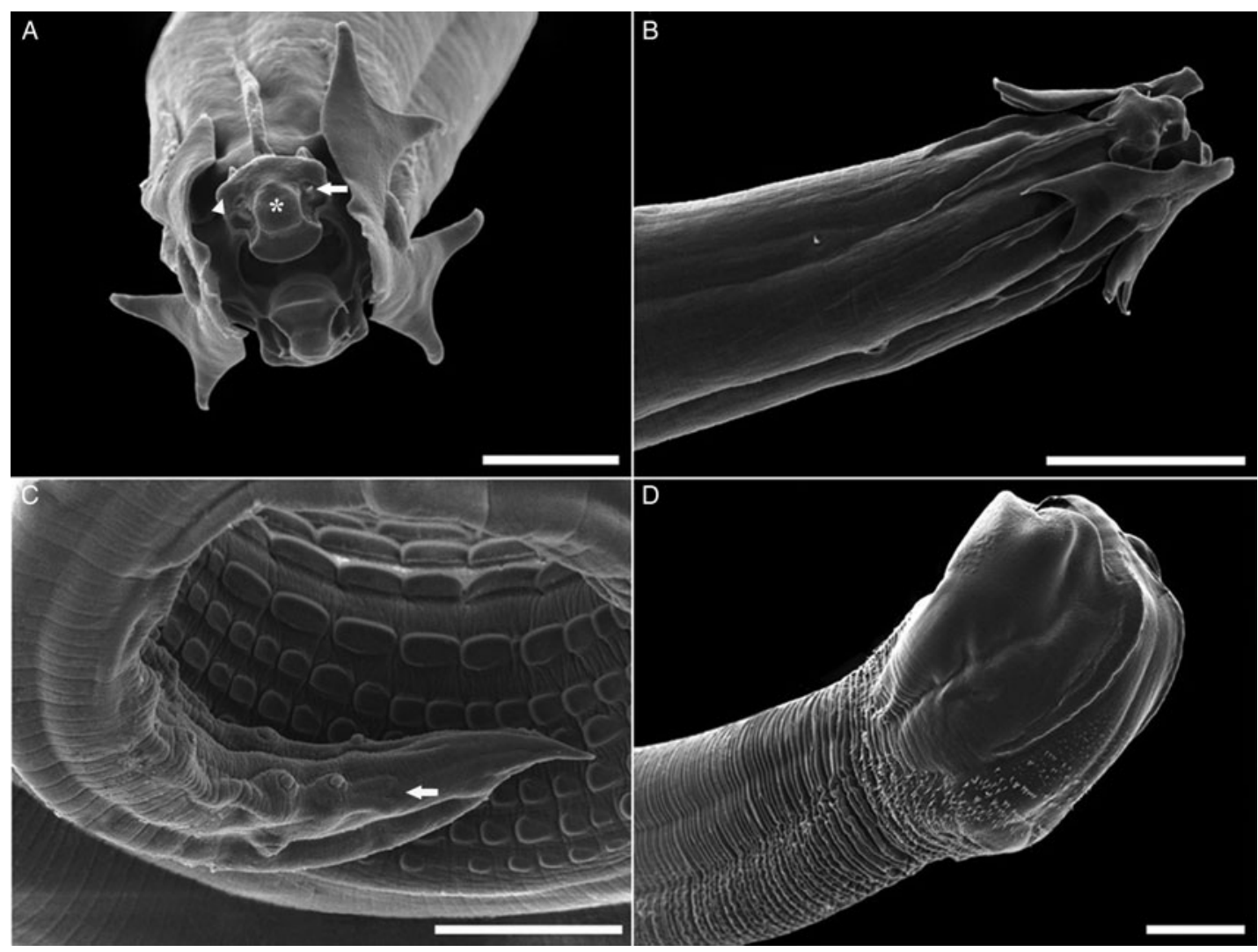

Fig. 4. Scanning electron micrographs of Hedruris dratini n. sp. (A) Apical view of male (arrowhead: sessile papillae; arrow: digitiform papillae; asterisk: amphid); (B) anterior end of male, sublateral view; (C) tail of male, ventral view (arrow: phasmid); (D) posterior end of female, subdorsal view. Scale bars: $100 \mu \mathrm{m}$.

adcloacal papillae (Petter, 1971; Hasegawa \& Otsuru, 1979), which are absent in the new species. Hedruris siredonis can also be distinguished from the new species by the distribution and number of caudal papillae in males: 20-2:2:16 (total number of papillae-precloacal:adcloacal:postcloacal + anterior cloacal lip) in H. siredonis vs. 18-0:0:18 in H. dratini n. sp. (Baird, 1858).

There are five species with the same distribution of caudal papillae in males as $H$. dratini n. sp. (i.e. 18-0:0:18), all of them from the Neotropics: $H$. orestiae, $H$. basilichtensis, $H$. moniezi, H. suttonae and H. bifida (Bursey \& Goldberg, 2000; Rossin \& Timi, 2016). However, none of them possess mammilated eggs. Additionally, females of $H$. moniezi are described as opistodelphic, those of $H$. suttonae and $H$. bifida are monodelphic, but Hedruris dratini n. sp. females are didelphic, prodelphic (Ibañez \& Córdova, 1976; Brugni \& Viozzi, 2010; Rossin \& Timi, 2016).

\section{Molecular analyses}

A total of six sequences (up to $889 \mathrm{bp}$ ) were yielded from subadults and adults of $H$. dratini n. sp. (GenBank accession numbers MK928970, MN233055-MN233060). The alignment of these sequences returned $701 \mathrm{bp}$ fragments, which exhibited $99.43 \%$ identity to each other, a single polymorphic site and three insertion/deletion events. A sequence of $840 \mathrm{bp}$ was also yielded from a subadult male of $H$. orestiae (GenBank accession number MN263058). By BLAST similarity analysis, the correct 18 S gene amplification was confirmed and no identical matches were found. The sequences obtained from $H$. dratini aligned closest to H. spinigera from New Zealand smelt (GenBank accession

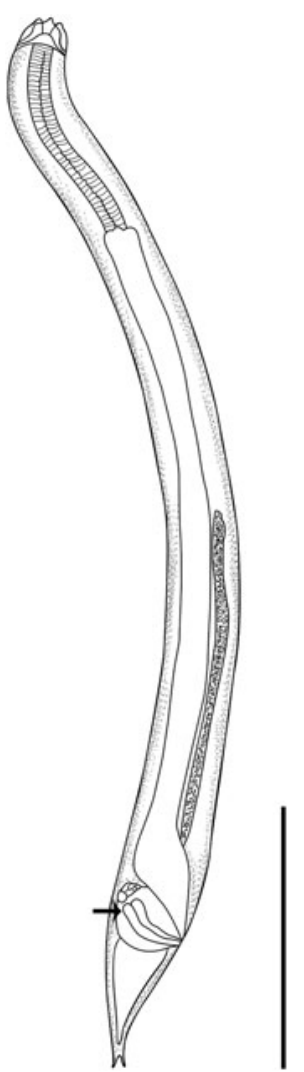

Fig. 5. Line drawing of male fourth-stage larva of Hedruris dratini n. sp. with primordial spicules (arrow), lateral view. Scale bar: $500 \mu \mathrm{m}$. 


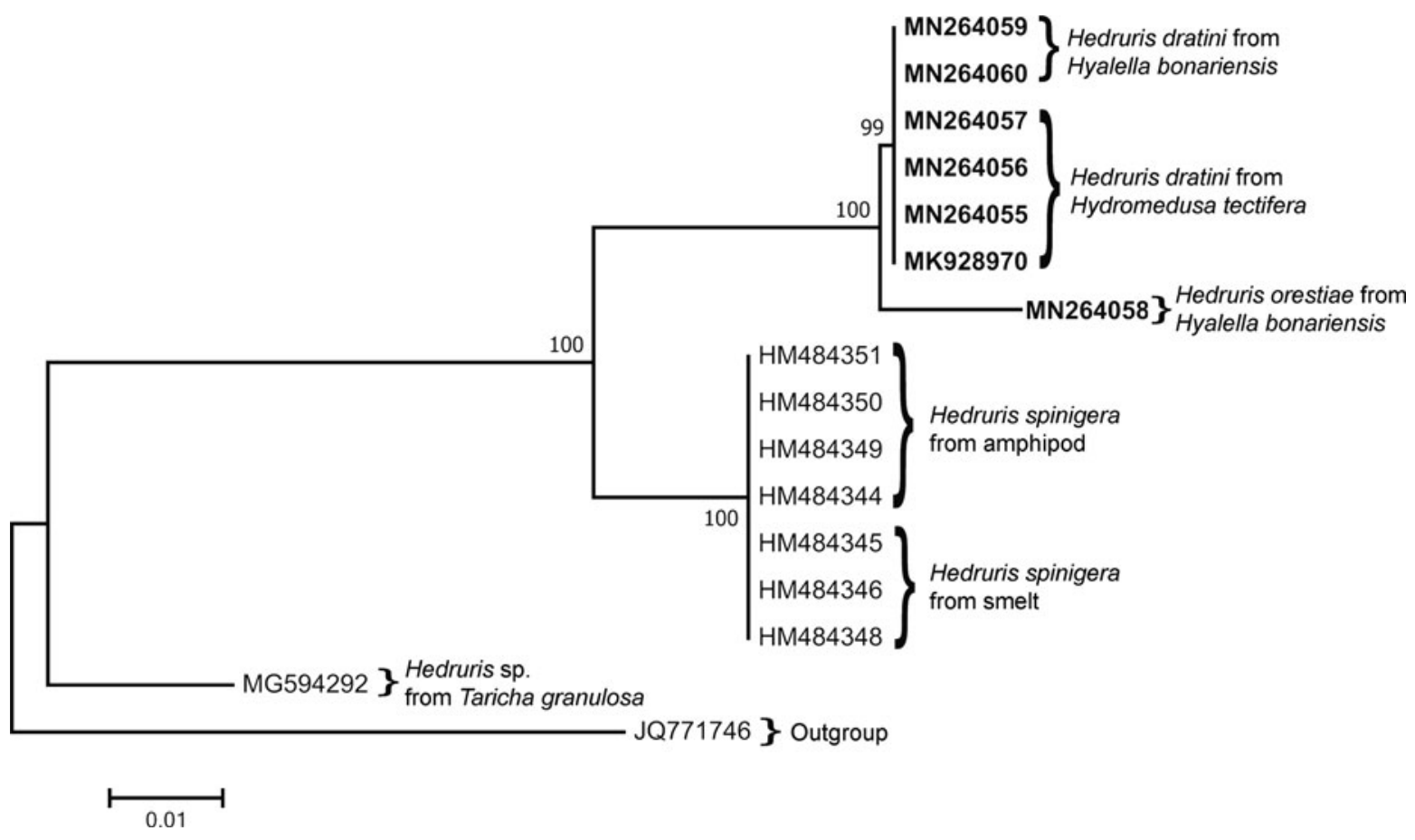

Fig. 6. Phylogenetic tree based on Hedruris rDNA sequences newly obtained in this study (bold type) compare with all Hedruris sequences available in GenBank using Maximum Likelihood method with a distance matrix calculation with K2P. A Spiruridae species was used as outgroup. The numbers at the nodes represent the percentages of 500 bootstrap replicates. Sequences are identified by GenBank accession numbers, taxa names and hosts.

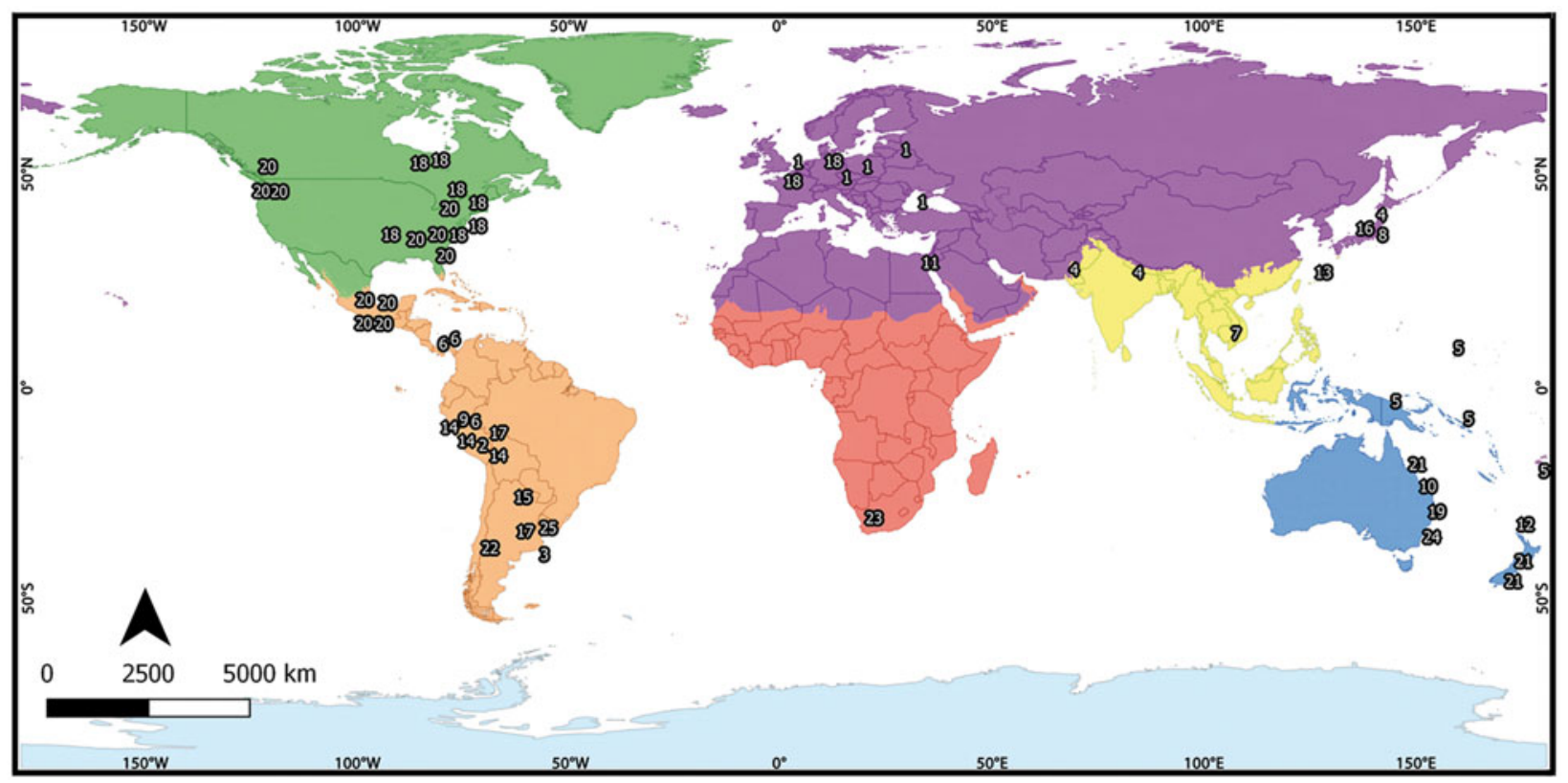

Fig. 7. Map of geographic distribution of Hedruris species: (1) H. androphora; (2) H. basilichtensis; (3) H. bifida; (4) H. bryttosi; (5) H. hanleyae; (6) H. heyeri; (7) H. hipsirhinae; (8) H. ijimai; (9) H. juninensis; (10) H. longispicula; (11) H. lutjanenses; (12) H. minuta; (13) H. miyakoensis; (14) H. moniezi; (15) H. mucronifer; (16) H. neobythitis; (17) H. orestiae; (18) H. pendula; (19) H. saltuarii; (20) H. siredonis; (21) H. spinigera; (22) H. suttonae; (23) H. transvaalensis; (24) H. wogwogensis; (25) H. dratini n. sp. Colours indicate the biogeographical provinces proposed by Udvardy (1975): green, Nearctic; orange, Neotropics; red, Afrotropics; violet, Palearctic; yellow, Indo-Malaya; blue, Australia; light violet, Oceania.

number HM484346) (95-96\% identity), followed by Hedruris sp. from American T. granulosa (GenBank accession number MG594292) (93-94\% identity).

The tree topology showed the isolates from subadults and adults of $H$. dratini n. sp. clustered together with a high bootstrap support of $99 \%$, and very closely with the isolate of $H$. orestiae obtained in our study (100\% bootstrap support). The isolates of $H$. spinigera from New Zealand smelt grouped as a sister clade (fig. 6).

Pairwise analyses showed that the genetic difference between $H$. dratini $\mathrm{n}$ sp. and $H$. orestiae was $1.3 \%$; between $H$. dratini $\mathrm{n}$ sp. and $H$. spinigera ranged from 4 to $4.1 \%$; and between $H$. dratini n. sp. and Hedruris sp. from T. granulosa ranged from 7 to $7.2 \%$. 
Table 1. Host and geographic distribution of Hedruris Nitzsch, 1821 species.

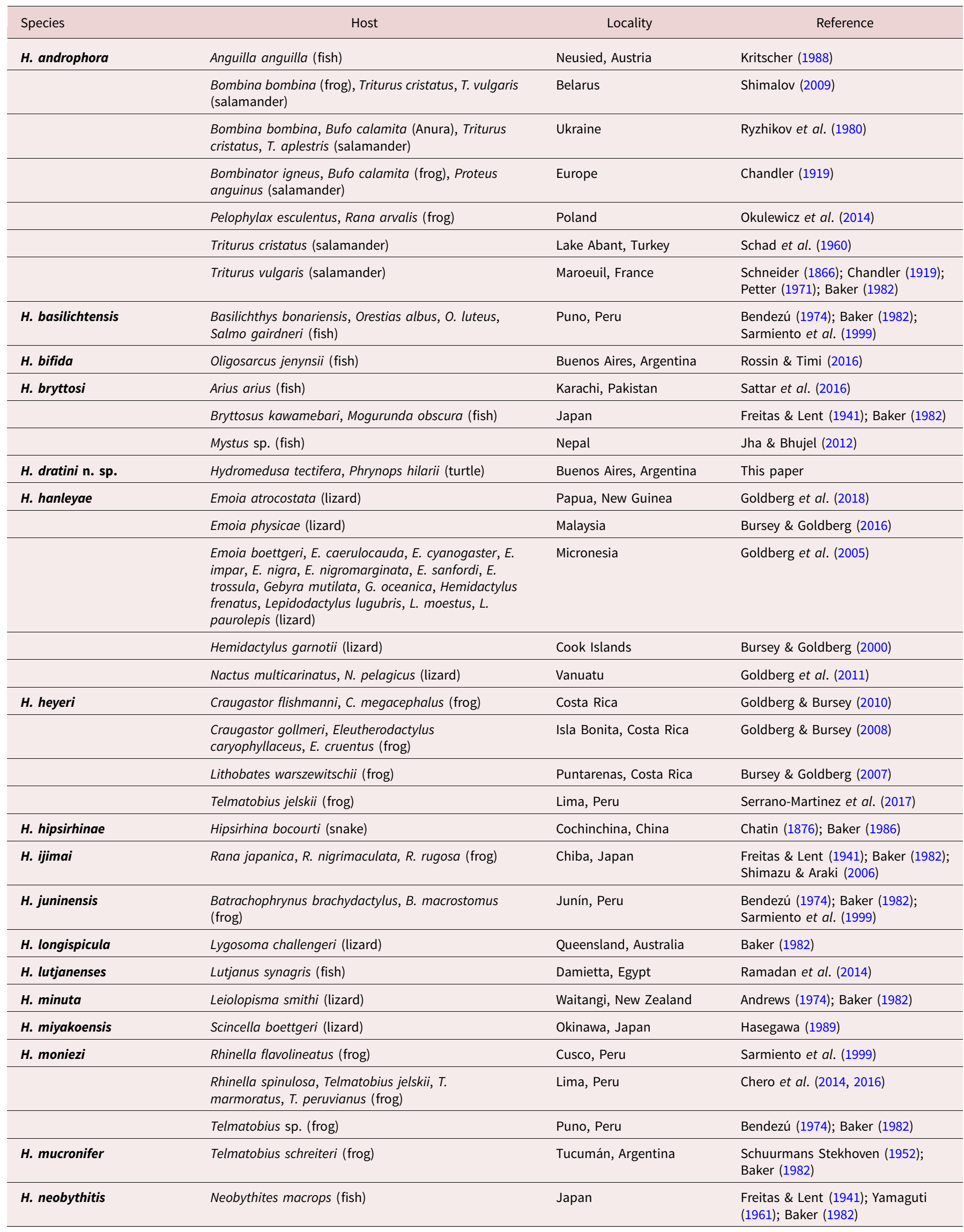


Table 1. (Continued.)

\begin{tabular}{|c|c|c|c|}
\hline Species & Host & Locality & Reference \\
\hline \multirow[t]{2}{*}{ H. orestiae } & $\begin{array}{l}\text { Orestias agassi, O. luteus, O. mullen, Salmo gairdneri, } \\
\text { Trichomycterus rivulatus (fish) }\end{array}$ & Puno, Peru & $\begin{array}{l}\text { Ibañez \& Córdova (1976); Baker } \\
\text { (1982); Sarmiento et al. (1999) }\end{array}$ \\
\hline & Hydromedusa tectifera (turtle) & Buenos Aires, Argentina & Palumbo et al. (2016) \\
\hline \multirow[t]{7}{*}{ H. pendula } & Clemmys guttata (turtle) & $\begin{array}{l}\text { Massachusetts, USA, and } \\
\text { Zoological Garden, } \\
\text { Germany }\end{array}$ & Leidy (1851); Baker (1986) \\
\hline & Esox niger (fish) & New York, USA & Baker (1982, 1986) \\
\hline & Clemmys guttata (turtle) & Ontario, Canada & Baker (1986) \\
\hline & Chrysemys picta (turtle) & $\begin{array}{l}\text { Massachusetts, USA and } \\
\text { Zoological Garden, } \\
\text { France }\end{array}$ & Baker (1986) \\
\hline & Emydoidea blandingi (turtle) & Ontario, Canada & Baker (1986) \\
\hline & Rana catesbeiana (frog) & Canada & Baker (1986) \\
\hline & Desmognathus brimleyorum (salamander) & Arkansas, USA & McAllister et al. (1995) \\
\hline H. saltuarii & Saltuarius moritzi (lizard) & $\begin{array}{l}\text { New South Wales, } \\
\text { Australia }\end{array}$ & Jones (2013) \\
\hline \multirow[t]{10}{*}{ H. siredonis } & Ambystoma cingulatum (salamander) & Florida, USA & Whiles et al. (2004) \\
\hline & Ambystoma gracile, Triturus torosus (salamander) & Oregon, USA & $\begin{array}{l}\text { Chandler (1919); Freitas \& Lent } \\
\text { (1941); Thorson (1956); Baker } \\
(1982)\end{array}$ \\
\hline & Ambystoma mexicanum (salamander) & Mexico & Baird (1858) \\
\hline & Ambystoma ordinarium, Ambystoma sp. (salamander) & Michoacán, Mexico & Baker (1986) \\
\hline & Ambystoma taylori, A. tigrinum (salamander) & Puebla, Mexico & Baker (1982, 1986) \\
\hline & Ambystoma tigrinum (salamander) & DF, Mexico & Baker (1986) \\
\hline & Desmognathus fuscus (salamander) & Georgia, USA & Baker (1986) \\
\hline & Rana clamitans (frog) & New Hampshire, USA & Muzzall \& Baker (1987) \\
\hline & Taricha granulosa (salamander) & $\begin{array}{l}\text { Oregon, USA and British } \\
\text { Columbia, Canada }\end{array}$ & Baker (1986) \\
\hline & Triturus viridescens (salamander) & North Carolina, USA & Walton (1930); Baker (1982) \\
\hline \multirow[t]{4}{*}{ H. spinigera } & $\begin{array}{l}\text { Agonostomus forsteri, Anguilla aucklandii, A. australis, } \\
\text { A. diefenbachii, Galaxias attenuatus, G. maculatus, } \\
\text { Gobiomorphus basalis, Oncorhynchus tschawytscha, } \\
\text { Retropinna retropinna, Rhombosolea plebeia, } R \text {. } \\
\text { tapirina, Salmo trutta (fish) }\end{array}$ & $\begin{array}{l}\text { Christchurch, New } \\
\text { Zealand }\end{array}$ & $\begin{array}{l}\text { Baylis (1931); Stokell (1936); Webb } \\
\text { (1973); Clark (1978); Baker (1982, } \\
\text { 1986); Jellyman (1989) }\end{array}$ \\
\hline & $\begin{array}{l}\text { Aldrichetta forsteri, Retropinna retropinna, Galaxias } \\
\text { maculatus, Perca fluviatilis, Rhombosolea retiaria, } \\
\text { Salmo trutta (fish) }\end{array}$ & $\begin{array}{l}\text { South Island, New } \\
\text { Zealand }\end{array}$ & Luque et al. (2010) \\
\hline & Anguilla reinhardtii (fish) & Queensland, Australia & Kennedy (1995) \\
\hline & $\begin{array}{l}\text { Geotria australis (lamprey), Leptoscopus macropygus, } \\
\text { Neochanna apoda (fish) }\end{array}$ & New Zealand & Blair (1984) \\
\hline H. suttonae & Galaxias maculatus, G. platei (fish) & Rio Negro, Argentina & Brugni \& Viozzi (2010) \\
\hline H. transvaalensis & Breviceps sylvestris (frog) & Woodbush, South Africa & $\begin{array}{l}\text { Baker (1982); Bursey \& Goldberg } \\
(2000)\end{array}$ \\
\hline H. wogwogensis & Lampropholis guichenoti (lizard) & $\begin{array}{l}\text { New South Wales, } \\
\text { Australia }\end{array}$ & Jones \& Resasco (2016) \\
\hline
\end{tabular}

\section{Double infection}

We occasionally found adults of $H$. orestiae and $H$. dratini n. sp. within the same host specimen. In some cases, $H$. orestiae females and $H$. dratini n. sp. of both sexes were observed together and none of the $H$. dratini n. sp. males were coiled around those females. In other cases, $H$. orestiae males were found together with $H$. dratini n. sp. of both sexes and, similarly, none of those males were coiled around $H$. dratini n. sp. females. In all these cases, $H$. orestiae females were non-gravid and we never found males and females of $H$. orestiae infecting the same individual host. 


\section{Host and geographic distribution}

Including the present paper, a total of 123 literature records have been found for Hedruris species worldwide (fig. 7, table 1). Both the reported species richness and number of records are greater in the southern than in the northern hemisphere ( 17 vs. nine species, and 75 vs. 48 records, respectively). Amphibians as definitive hosts show the highest number of records (46, of which 26 in frogs and 20 in salamanders), followed by 41 records in fish, 35 in reptilians (24 in lizards, ten in turtles and one in snakes) and only one record in lampreys.

\section{Discussion}

As regards their life cycles, Hedruris species require an isopod or amphipod as intermediate host in which all larval stages develop up to the subadult stage. Subsequently, sexual maturity is reached in the definitive host (Anderson, 2000). Petter (1971) found $H$. androphora in the salamander Triturus vulgaris (Linneus, 1758) and studied its development in the isopod Asellus aquaticus (Linneus, 1758) by allowing them to ingest larvated eggs. First-stage larvae invade the isopod haemocoel close to the cephalic end. Subsequently, development to the subadult stage takes place, but sexual maturity is only reached in the stomach of the definitive host (Anderson, 2000).

In the Hy. bonariensis specimens collected from both the stomach contents and the natural aquatic environment, subadults of $H$. dratini n. sp. were found inside the haemocoel or penetrating the amphipod's cuticle towards the stomach lumen of the definitive host. Subadults have all the characteristics of the adults and are ready to leave the intermediate host, invade the stomach of the definitive host and reproduce, as was described by Moravec (1998). Mature and gravid H. dratini n. sp. were found both in the stomach and faeces of the examined turtles. Larvated eggs were also present in the faeces. It can, therefore, be deduced that the life cycle of $H$. dratini n. sp. begins when the female releases the eggs in the digestive tract of the turtle, which are later expelled together with the faeces. Once in the aquatic environment, $H y$. bonariensis ingest the nematodes eggs, which hatch inside the digestive tract. The first-stage larva migrates to the haemocoel and moult repeatedly to reach the subadult stage. When a turtle swallows the infected amphipods, the subadult is released and reaches sexual maturity in the stomach. Eggs are released with the faeces into the environment, repeating the cycle. This is the first report of the life cycle of a species of Hedruris parasite of reptilians.

According to Mayr (1942: 247), 'species are groups of natural populations that potentially interbreed, and are reproductively isolated from other similar groups', which is evidenced by these two co-occurring species ( $H$. dratini n. sp. and $H$. orestiae), reinforcing the aforementioned morphological distinction between them. We are convinced that the low prevalence of $H$. orestiae found is due to the interspecific competition with $H$. dratini n. sp., which dominates over $H$. orestiae in this population of Hyd. tectifera. These results contrast with Palumbo et al. (2016), who found only $H$. orestiae in Hyd. tectifera in a stream $100 \mathrm{~km}$ away from the study area of the present study.

Sequencing the 18S rRNA gene is a valuable tool for the characterization of isolates to the genus or species level (Liu, 2011; Yooyangket et al., 2018). Present molecular results support the classification of the new species into the genus Hedruris, corroborating that $H$. dratini n. sp. differs from the other two species submitted in the GenBank (Luque et al., 2010; Choudhury \& Nadler, 2018), because the identity is less than $97 \%$.
Additionally, present findings confirm that larval nematodes found in amphipods are the same species as those found in turtles. The partial sequences of $18 \mathrm{~S}$ gene analysed in this study are highly conserved among the Hedruris species. Although the genetic distance between $H$. dratini n. sp. and $H$. orestiae is low, the morphological characters distinguish these two closely related species, which share both the intermediate and definitive host. This point deserves further molecular analysis using other genetic markers (e.g. COI, ITS), which tend to be more variable, providing more reliable species-specific identification (Avise, 1994; Palomares-Rius et al., 2017). However, the obtained sequence information can be considered as a useful resource for taxonomic and phylogenetic studies.

Despite a broad distribution worldwide, South America is the region with the greatest number of species described. Even if areas in which few or no studies have been conducted are taken into account, the distribution map of Hedruris species illustrates that members of the genus follow a Gondwanian distribution (fig. 7, table 1). According to the biogeographic provinces proposed by Udvardy (1975), Hedruris species are mostly distributed in the Neotropics (ten species, 38 reports), followed by Australia (six species, 30 reports), the Palearctic (six species, 20 reports), the Nearctic (two species, 16 reports), Oceania (one species, 15 reports), Indo-Malaya (three species, three reports) and the Afrotropics (one species, one report). This analysis allows us to hypothesize that the speciation and radiation of Hedruris occurred first in Gondwana, probably in fish, and that, subsequently, species dispersed to other hosts as well as to the northern hemisphere because of the great plasticity and host adaptability of the genus.

Hedruris dratini n. sp. is the fifth valid species of the genus in Argentina, which suggests a great adaptive success of the genus in this country.

Acknowledgements. We thank Leandro Alcalde (Instituto de Limnología Dr R.A. Ringuelet) for providing the hosts, Kabe Solas for assisting with the plates and Inés Cesar for the identification of amphipods. We are also grateful to Patricia Sarmiento from the Servicio de Microscopía Electrónica de Barrido del Museo de La Plata (FCNyM, UNLP), Walter Ferrari and Diego Balcazar for their support in obtaining molecular data and to Pilar Martínez (English Public Translator) for the revision of the manuscript. This research was partially funded by UNLP (N828 to JD).

Financial support. This research was partially funded only by Universidad Nacional de La Plata (N828 to JD).

Conflicts of interest. None.

\section{References}

Altschul SF, Madden TL, Schäffer AA, Zhang J, Zhang Z, Miller W and Lipman DJ (1997) Gapped BLAST and PSI-BLAST: a new generation of protein database search programs. Nucleic Acids Research 25, 3389-3402.

Anderson RC (2000) Nematode parasites of vertebrates: their development and transmission. 1st edn. 650 pp. Wallingford, CABI Publishing.

Andrews JRH (1974) A new species of Hedruris (Nematoda: Spirurida) from the skink Leiolopsima smithi. New Zealand Journal of Zoology 1, 329-332.

Avise JC (1994) Molecular markers, natural history and evolution. 1st edn. 511 pp. New York, Chapman and Hall.

Baird W (1858) Description of two new species of Entozoa. Proceedings of the Zoological Society of London 26, 224-225.

Baker MR (1982) Systematics and zoogeography of three new nematode parasites of the frog Breviceps sylvestris sylvestris FitzSimons from South Africa. Canadian Journal of Zoology 60, 3134-3142. 
Baker MR (1986) Revision of Hedruris Nitzsch (Nematoda: Habronematoidea) from aquatic vertebrates of North America. Canadian Journal of Zoology 64, $1567-1572$.

Baylis HA (1931) VIII.-A species of the Nematode genus Hedruris occurring in the trout in New Zealand. Annals and Magazine of Natural History 7, 105-114.

Bendezú LS (1974) Nueva especie del genero Hedruris Nitzsch, 1821 Nematode Parasito de Batrachophrynus brachydactylus Peters, 1873. Revista Ciencias Universidad Nacional Mayor de San Marcos 70, 45-51.

Blair D (1984) A checklist and bibliography of parasites of New Zealand freshwater fish. Mauri ora 11, 5-50.

Bonfield JK, Smith KF and Staden R (1995) A new DNA sequence assembly program. Nucleic Acids Research 23, 4992-4999.

Brugni NL and Viozzi GP (2010) A new hedrurid species (Nematoda) from galaxiid fishes in Patagonia (Argentina), and infection of amphipods as intermediate host. Journal of Parasitology 96, 109-115.

Bursey CR and Goldberg SR (2000) Hedruris hanleyae n. sp. (Nematoda: Hedruridae) from Hemidactylus garnotii (Sauria: Gekkonidae) from the Cook Islands. Oceania. Journal of Parasitology 86, 556-559.

Bursey CR and Goldberg SR (2007) New species of Hedruris (Nematoda: Hedruridae), Anuracanthorhynchus lutzi (Hamann, 1891) n. comb. and other helminths in Lithobates warszewitschii (Anura: Ranidae) from Costa Rica. Caribbean Journal of Science 43, 1-10.

Bursey CR and Goldberg SR (2016) A new species of Physalopteroides (Nematoda: Physalopteridae) in Emoia atrocostata (Squamata: Scincidae) from Peninsular Malaysia. Comparative Parasitology 83, 221-226.

Bush AO, Lafferty KD, Font JM and Shostak AW (1997) Parasitology meets ecology: definitions, clarifications, examples and Margolis et al. revisited. Journal of Parasitology 83, 575-583.

Chandler AC (1919) On a species of Hedruris occurring commonly in the western newt, Notophthalmus torosus. Journal of Parasitology 5, 116-122.

Chatin MJ (1876) Etudes helminthologiques. Deuxième serie. Comptes Rendus de l'Association Francaise pour l'Avancement des Sciences, Paris 4, 801-805.

Chero J, Cruces C, Iannacone J, Sáez G, Alvariño L, da Silva RJ and Morales VR (2014) Gastrointestinal parasites in three species of Telmatobius (Anura: Telmatobiidae) in the high Andes, Peru. Neotropical Helminthologia 8, 439-461.

Chero J, Cruces C, Iannacone J, Sáez G, Alvariño L, Luque J and Morales VR (2016) Community of helminth parasites of thorny toad Rhinella spinulosa (Anura: Bufonidae) of Peru. Revista de Investigaciones Veterinarias de Perú 27, 114-129.

Choudhury A and Nadler SA (2018) Phylogenetic relationships of spiruromorph nematodes (Spirurina: Spiruromorpha) in North American freshwater fishes. Journal of Parasitology 104, 496-504.

Clark WC (1978) Head morphology and prehensile adaptations in Hedruris spinigera (Nematoda: Spirurida). New Zealand Journal of Zoology 5, 497-501.

Floyd RM, Rogers AD, Lambshead JD and Smith CR (2005) Nematode-specific PCR primers for the $18 \mathrm{~S}$ small subunit rRNA gene. Molecular Ecology Notes 5, 611-612.

Freitas JET and Lent H (1941) Contribuicao ao estudo do genero Hedruris Nitzsch, 1821 (Nematoda). Papeis Avulsos de Zoologia Universidiade de Sao Paulo, Museu de Zoologia 1, 121-142.

Goldberg SR and Bursey CR (2008) Helminths from 10 Species of Brachycephalid frogs (Anura: Brachycephalidae) from Costa Rica. Comparative Parasitology 75, 255-262.

Goldberg SR and Bursey CR (2010) Helminth biodiversity of Costa Rican anurans (Amphibia: Anura). Journal of Natural History 44, 1755-1787.

Goldberg SR, Bursey CR and Fisher RN (2005) Helminth records from eleven species of Emoia (Sauria: Scincidae) from Oceania. Pacific Science 59, 609-614.

Goldberg SR, Bursey CR, Hamilton AM and Austin CC (2011) Gastrointestinal helminth communities of two gekkonid lizard species, Nactus multicarinatus and Nactus pelagicus (Squamata: Gekkonidae), from the Republic of Vanuatu, Oceania. Journal of Natural History 45, 1983-1993.

Goldberg SR, Bursey CR and Kraus F (2018) Helminths from Emoia physicae (Squamata: Scincidae) from Papua New Guinea. Pacific Science 72, $1-10$.
Hasegawa H (1989) Neoentomelas asatoi gen. et sp. n. (Nematoda: Rhabdiasidae) and Hedruris miyakoensis sp. n. (Nematoda: Hedruridae) from skinks of the Ryukyu Archipelago, Japan. Proceedings of the Helminthological Society of Washington 56, 145-150.

Hasegawa H and Otsuru M (1979) Life history of an amphibian nematode, Hedruris ijimai Morishita, 1926 (Hedruridae). Japan Journal of Zoology 28, 89-97.

Ibañez HN and Córdova BE (1976) Cuatro especies nuevas de nematodos del sur del Perú y redescripción de Hedruris orestiae Moniez, 1889. Memorias do Instituto Oswaldo Cruz 74, 231-254.

Jellyman DJ (1989) Occurrence of the nematode Hedruris spinigera in the stomachs of freshwater eels. New Zealand Journal of Zoology 16, 185-189.

Jha DK and Bhujel RC (2012) Incidence of fish diseases and management practices in Nepal. pp. 160-164 in MK Shrestha and J Pant (Eds) Smallscale aquaculture for increasing resilience of rural livelihoods in Nepal. Kathmandu, Nepal, 5-6 February. Chitwan, Nepal, Tribhuvan University Rampur.

Jones HI (2013) Gastrointestinal nematodes from three species of leaf-tailed geckos (Reptilia: Saltuarius spp.), with descriptions of new species of Skrjabinodon (Oxyuroidea: Pharyngodonidae) and Hedruris (Habronematoidea: Hedruridae). Comparative Parasitology 80, 47-59.

Jones HI and Resasco J (2016) A new species of Hedruris (Nematoda: Hedruridae) from the Australian Skink Lampropholis guichenoti (Reptilia: Scincidae). Comparative Parasitology 83, 173-177.

Kennedy CR (1995) Richness and diversity of macroparasite communities in tropical eels Anguilla reinhardtii in Queensland, Australia. Parasitology 111, 233-245.

Kimura M (1980) A simple method for estimating evolutionary rates of base substitutions through comparative studies of nucleotide sequence. Journal of molecular evolution 16, 111-120.

Kritscher E (1988) Fishes of Neusiedlersee and their parasites. IV. Nematoda. Annalen des Naturhistorischen Museums in Wien 7, 123-126.

Kumar S, Stecher G and Tamura K (2016) MEGA7: Molecular Evolutionary Genetics Analysis version 7.0 for bigger datasets. Molecular Biology and Evolution 33, 1870-1874.

Larkin MA, Blackshields G, Brown NP, et al. (2007) Clustal W and Clustal X version 2.0. Bioinformatics 23, 2947-2948.

Legler JM (1977) Stomach flushing: a technique for chelonian dietary studies. Herpetologica 33, 281-284.

Leidy J (1851) Contributions to helminthology. Proceedings of the Academy of Natural Sciences of Philadelphia 5, 205-210.

Liu D (2011) Molecular detection of human bacterial pathogens. 1st edn. Broken Sound Parkway, New York, CRC Press, 1278 pp.

Luque JL, Vieira FM, Herrmann K, King TM, Poulin R and Lagrue C (2010) New evidence on a cold case: trophic transmission, distribution and host-specificity in Hedruris spinigera (Nematoda: Hedruridae). Folia Parasitologica 57, 223231.

Mayr E (1942) Systematics and the origin of species. 1st edn. 338 pp. New York, Columbia University Press.

McAllister CT, Bursey CR, Upton SJ, Trauth SE and Conn DB (1995) Parasites of Desmognathus brimleyorum (Caudata: Plethodontidae) from the Ouachita Mountains of Arkansas and Oklahoma. Journal of Helminthology 62, 150-156.

Moravec F (1998) Nematodes of freshwater fishes of the Neotropical region. 1st edn. 464 pp. Praha, Academia.

Moravec F and Vargas-Vázquez J (1998) Some endohelminths from the freshwater turtle Trachemys scripta from Yucatán, México. Journal of Natural History 32, 455-468.

Muzzall PM and Baker MR (1987) First report of Hedruris siredonis (Nematoda: Hedruridae) from North American frogs. Proceedings of the Helminthological Society of Washington 54, 276-277.

Okulewicz A, Hildebrand J, Lysowski R, Bunkowska $\mathrm{K}$ and Perec-Matysiak A (2014) Helminth communities of green and brown frogs from Poland (Lower Silesia region). Journal of Herpetology 48, 34-37.

Palomares-Rius JE, Cantalapiedra-Navarrete C, Archidona-Yuste A, Subbotin SA and Castillo P (2017) The utility of mtDNA and rDNA for barcoding and phylogeny of plant-parasitic nematodes from Longidoridae (Nematoda, Enoplea). Scientific reports 7, 10905. 
Palumbo EO, Capasso S, Cassano MJ, Alcalde L and Diaz JI (2016) Spiroxys contortus (Rudolphi, 1819) and Hedruris orestiae (Moniez, 1889) in Argentine turtles. Check List 12, 1993.

Petter AJ (1971) Redescription d'Hedruris androphora Nitzsch, 1821 (Nematoda: Hedruridae) et étude de son développement chez l'hôte intermédiare. Annales de Parasitologie Humaine et Comparée 46, 479-495.

Ramadan MM, Awad ER and Taha RG (2014) Anatomical and surface morphology of Hedruris lutjanenses sp. n. (Nematoda: Hedruridae) from the common marine water fish Lutjanus synagris in Damietta, Egypt. Journal of Egypt Society of Parasitology 44, 309-320.

Rossin MA and Timi JM (2016) A new species of Hedruris Nitzsch, 1821 (Nematoda: Hedruridae) parasitic in the freshwater fish Oligosarcus jenynsii (Gunther, 1864) (Characidae) from Argentina. Systematic Parasitology 93, 899-904.

Rozsa L, Reiczigel J and Majoros G (2000) Quantifying parasites in samples of hosts. Journal of Parasitology 86, 228-232.

Ryzhikov KM, Sharpilo VP and Shevchenko NN (1980) Helminths of amphibians of the fauna of the USSR. 1st edn. 278 pp. Moscow, Nauka.

Sarmiento L, Tantaleán M and Huiza A (1999) Nematodos parásitos del hombre y de los animales en el Perú. Revista Peruana de Parasitología 14, 9-65.

Sattar A, Khan A, Khatoon N and Mujahid A (2016) Occurrence of some nematode parasites in the gastrointestinal tract of Ariidae (Teleostei: Siluriformes) catfish, Arius arius (Hamilton, 1822) from Karachi coast. Pakistan Journal of Nematology 34, 205-212.

Schad GA, Kuntz RE and Wells WH (1960) Nematode parasites from Turkish vertebrates an annotated list. Canadian Journal of Zoology 38, 949-963.

Schneider A (1866) Monographie der Nematoden. 1st edn. 435 pp. Berlin, Harvard College.

Schuurmans Stekhoven Jr JH (1952) Nematodos parasitarios de anfibios, pájaros y mamíferos de la República Argentina. Acta Zoológica Lilloana 10, 315-400.
Serrano-Martinez E, Quispe MH, Plascencia LP and Hinostroza EM (2017) Zoonotic parasites in frogs used for preparing beverages for human consumption in Lima, Peru. Revista de Investigaciones Veterinarias de Perú 28, 642-649.

Shimalov VV (2009) Helminth fauna of amphibians (Vertebrata: Amphibia) in the republic of Belarus. Parazitologiya 43, 118-128.

Shimazu T and Araki J (2006) A list of the helminth parasite specimens deposited in the Department of Zoology, the University Museum, the University of Tokyo. The University Museum Material Report 62, 151-161.

Stokell G (1936) The nematode parasites of Lake Ellesmere trout. Transactions and Proceedings of the Royal Society of New Zealand 66, 80-96.

Thorson RE (1956) Proteolytic activity in extracts of the esophagus of adults of Ancylostoma caninum and the effect of immune serum on this activity. Journal of Parasitology 42, 21-25.

Udvardy MDF (1975) A Classification of the Biogeographical Provinces of the World. IUCN Occasional Paper No. 18. 1st edn. 49 pp. Morges, Switzerland, International Union for Conservation of Nature and Natural Resources.

Walton AC (1930) A new Hedruris from Diemyctylus viridescens. Journal of Parasitology 17, 49-51.

Webb BF (1973) Fish populations of the Avon-Heathcote estuary. New Zealand Journal of Marine and Freshwater Research 7, 301-305.

Whiles MR, Jensen BJ, Palis JG and Dyer WG (2004) Diets of larval flatwoods salamanders, Ambystoma cingulatum, from Florida and South Carolina. Journal of Herpetology 38, 208-214.

Yamaguti S (1961). Systema Helminthum. Vol. III. The nematodes of vertebrates. 1st edn. 679 pp. New York, Interscience Publisher.

Yooyangket T, Muangpat P, Polseela R, Tandhavanant S, Thanwisai A and Vitta A (2018) Identification of entomopathogenic nematodes and symbiotic bacteria from Nam Nao National Park in Thailand and larvicidal activity of symbiotic bacteria against Aedes aegypti and Aedes albopictus. PloS one 13, e0195681. 